\title{
Increased Ferritin Levels in the Fluid of Thyroid Cyst
}

\author{
Masao ISHIDA, Yoshihiro KAJITA, YoshiYuki NAKAJIMA, \\ YASUAKI URA*, YUKIO OCHI*, TAKaSHI HACHIYA***, \\ HAMAO IJICHI*** AND TADAYOSHI MIYAZAKI**** \\ Department of Internal Medicine, Nantan General Hospital, Yagi, \\ Kyoto 629-01, *Central Clinical Laboratory, Shiga University of \\ Medical Science, Otsu, Shiga 520-21, **Second Department of \\ Internal Medicine and ****:Radiology Department, Kyoto \\ Prefectural University of Medicine, Kyoto 620
}

\begin{abstract}
High ferritin levels in the aspirate of thyroid cyst (Six yellow clear, 4 yellow turbid and 10 chocolate colored turbid) without apparent sings of malignancy were found. The mean concentration in the $3,000 \times \mathrm{g}$ supernatant of the fluid was $40,116 \mathrm{ng} / \mathrm{ml}$, and the $3,000 \times \mathrm{g}$ precipitate was $11,147 \mathrm{ng} / \mathrm{ml}$. All cases showed normal levels of serum ferritin. Con A binding with ferritin was distributed from low to high. These ferritins showed a molecular weight of approximately 450,000 which was the same as found in human spleen and liver.

The continuous increase in ferritin levels in thyroid cyst fluid was found by a chronological study in some cases.

When tumor markers such as CEA, NCA, CA $19-9$ and $\alpha_{1}$-acid glycoprotein $\left(\alpha_{1}-\mathrm{AG}\right.$, acute phase reactant) were examined simultaneously, an increase in some of the cyst fluid was observed. However, the incidence and the rate of increase of these tumor markers and acute phase reactant were low compared to ferritin. Neither a correlation between ferritin and CEA, nor between ferritin and CA 19-9 was found.

The increase in ferritin in thyroid cyst fluids may be due to the increased synthesis, release and storage by the inflammatory cells.
\end{abstract}

Ferritin is an iron storage protein which is present in liver, spleen, heart and other tissues (Walters et al., 1973; Jacobs et al., 1975). The ferritin molecule is composed of a protein shell and iron core, and has a molecular weight of 450,000 (Jacobs and Worwood, 1976).

The development of radioimmunoassay (RIA) has made possible the measurement of infinitesimal serum protein levels. The

Received October 1, 1984 measurement of the ferritin with RIA was developed by Addison et al. (1972). The measurement of serum ferritin levels has been considered as a useful marker for the detection and monitoring of malignant diseases by some investigators (Niitsu and Urushizaki, 1978), although ferritin is not a tumor specific index.

Recently, we found high ferritin concentrations in the aspirate of thyroid cyst, and investigated the properties of ferritin in the cyst fluid. This report describes the 
experimental results including estimation of other tumor associated antigens, acute phase reactant and thyroglobulin in thyroid cyst fluids.

\section{Materials and Methods}

\section{1) Samples}

Aspirates of thyroid cyst and sera in 20 patients (1 man, 19 women) with thyroid cyst without malignancy were used. There were 6 yellow clear, 4 yellow turbid and 10 chocolate colored turbid fluids. Aspirates of thyroid cyst were divided into the supernatant and precipilate by centrifugation at $3,000 \times \mathrm{g}$ for $30 \mathrm{~min}$. The precipitate was resuspended in a volume equal to that of the supernatant by adding 0.1 $M$ phosphate buffer $\mathrm{pH} 7.8$. These preparations were frozen at $-20^{\circ} \mathrm{C}$ until use. After thawing, they were centrifuged at $25,000 \times \mathrm{g}$ for $60 \mathrm{~min}$ at $4^{\circ} \mathrm{C}$, and the supernatant was used for RIA.

Five partient's were investigated chronologically for changes in ferritin levels in cyst fluids of thyroid. Four thyroid tissues were obtained at operation from patients with hyperthyroidism. The tissue was homogenized in $0.1 \mathrm{M}$ phosphate buffer, pH 7.8. Fifty percent $(\mathrm{w} / \mathrm{v})$ thyroid homogenate was centrifuged at $25,000 \times \mathrm{g}$ for 60 $\min$ at $4^{\circ} \mathrm{C}$. The supernatant was used for RIA.

Sera were obtained from 10 volunteers (5 men, 5 women) who had mean ferritin levels of $82 \pm 41 \mathrm{ng} / \mathrm{ml}$ (mean $\pm \mathrm{SD}$ ), and from 5 patients with cancer ( 2 lung cancer; 457 (mean), 1 liver cancer; 597, 1 pancreas cancer; 859 and 1 uterus cancer; 412) who had mean ferritin levels of 556 $\mathrm{ng} / \mathrm{ml}$. Tumor tissue of hepatoma was obtained at autopsy, then $20 \%(w / v)$ homogenate was centrifuged at $25,000 \times \mathrm{g}$ for $60 \mathrm{~min}$ to obtain the supernatant.

\section{2) Determination of ferritin and other protein} levels

Ferritin (Travenol Co. Boston), CEA (Commissariat A L'energie Atomique CIS, France), CA 19-9 (CIS) and thyroglobulin (Eiken Lab. Tokyo, Japan) were measured using commercial RIA kits. Non-specific cross-reacting antigen (NCA) levels were also measured with the RIA method developed in our lab (Hamazu et al., 1984). $\alpha_{1}$-acid glycoprotein $\left(\alpha_{1}-\mathrm{AG}\right)$ levels were measured with commercial single radial immunodiffusion kits (MBL, Tokyo, Japan). The normal values were ferritin; $<200 \mathrm{ng} / \mathrm{ml}, \mathrm{CEA} ;<10$ $\mathrm{ng} / \mathrm{ml}, \mathrm{CA} 19-9 ;<37 \mathrm{U} / \mathrm{ml}$, thyroglobulin ; <20 $\mathrm{ng} / \mathrm{ml}, \mathrm{NCA} ;<200 \mathrm{ng} / \mathrm{ml}$ and $\alpha_{1}-\mathrm{AG} ; 30-95$ $\mathrm{mg} / \mathrm{dl}$, respectively. Total proteins were determined by Lowry's method (Lowry et al., 1951).

\section{3) Estimations of thyroid function}

Thyroxine (T4), triiodothyronine (T3) and thyroid stimulating hormone (TSH) were measured by the methods reported previously (Ishida et al., 1982). Normal values for T4, T3 and TSH were $5.1-11.2 \mu \mathrm{g} / \mathrm{dl}, 0.8-2.0 \mathrm{ng} / \mathrm{ml}$ and $<5$ $\mu \mathrm{U} / \mathrm{ml}$, respectively.

\section{4) Gel-filtration on Sepharose 6B}

One $\mathrm{ml}$ of the supernatant obtained from the aspirate $(355,800 \mathrm{ng}$ ferritin/ml) was fractionated on Sepharose 6B (Pharmacia, Uppsala) column (120 $\times 1.5 \mathrm{~cm})$ in $0.05 \mathrm{M}$ phosphate buffer, $\mathrm{pH} 7.8$. These fractions were monitored at $280 \mathrm{~nm}$ for protein and collected in $2 \mathrm{ml}$ aliquots. These fractions were used for ferritin determination. 'rs5r-label'ed' human spleen ferritin (CIS-RIA' kit, about $100,000 \mathrm{cpm} / \mathrm{ml}$ ) or ${ }^{125}$ I-labeled human liver ferritin (Travenol-RIA kit, about 150,000 $\mathrm{cpm} / \mathrm{ml}$ ) was mixed with $0.5 \mathrm{ml}$ of normal human serum (NHS), before fractionation on Sepharose 6B column.

\section{5) Affinity chromatography with Con A-Sepha- rose}

Each aspirate of thyroid cyst $(100 \mu \mathrm{l})$ was mixed with $250 \mu \mathrm{l}$ of Con A-Sepharose (Pharmacia, Uppsala) which had been equilibrated with $0.1 \mathrm{M}$ acetate buffer ( $\mathrm{pH} 6.0$ ) containing $1 \mathrm{mM}$ $\mathrm{MgCl}_{2}, \mathrm{MnCl}_{2}$ and $\mathrm{CaCl}_{2}$, and these mixtures were allowed to stand for $24 \mathrm{hr}$ at $4^{\circ} \mathrm{C}$. The supernant was obtained by centrifugation at 3,000 $\mathrm{rpm}$ for $30 \mathrm{~min}$.

\section{Results}

1) Ferritin levels in the aspirate of thyroid cyst without malignancy

When ferritin level in 4 cases (No. 1-4) of yellow turbid fluid and 10 cases (No. 514) of chocolate colored turbid fluid was examined, the $3,000 \times \mathrm{g}$ precipitate fraction showed a higher ferritin level than the 3,000 
$\times g$ supernatant fraction. Six yellow clear fluids (No. 15-20) that had no precipitate fraction also showed high ferritin levels $(>1,000 \mathrm{ng} / \mathrm{ml}$ ) (Fig. 1). Mean ferritin levels were $40,116 \mathrm{ng} / \mathrm{ml}$ in the $3,000 \times \mathrm{g}$ supernatant fraction and $11,147 \mathrm{ng} / \mathrm{ml}$ in the $3,000 \times \mathrm{g}$ precipitate fraction (released fraction after freezing), respectively.
All patients' sera showed normal ferritin levels $(<100 \mathrm{ng} / \mathrm{ml})$. There was no correlation between serum ferritin levels and aspirate ferritin levels in patients with thyroid cyst (Fig. 2).

The mean level of ferritin in the 25,000 $\mathrm{Xg}$ supernatant of thyroid tissues was 1,013 $\mathrm{ng} / \mathrm{ml}$ (Table 1).
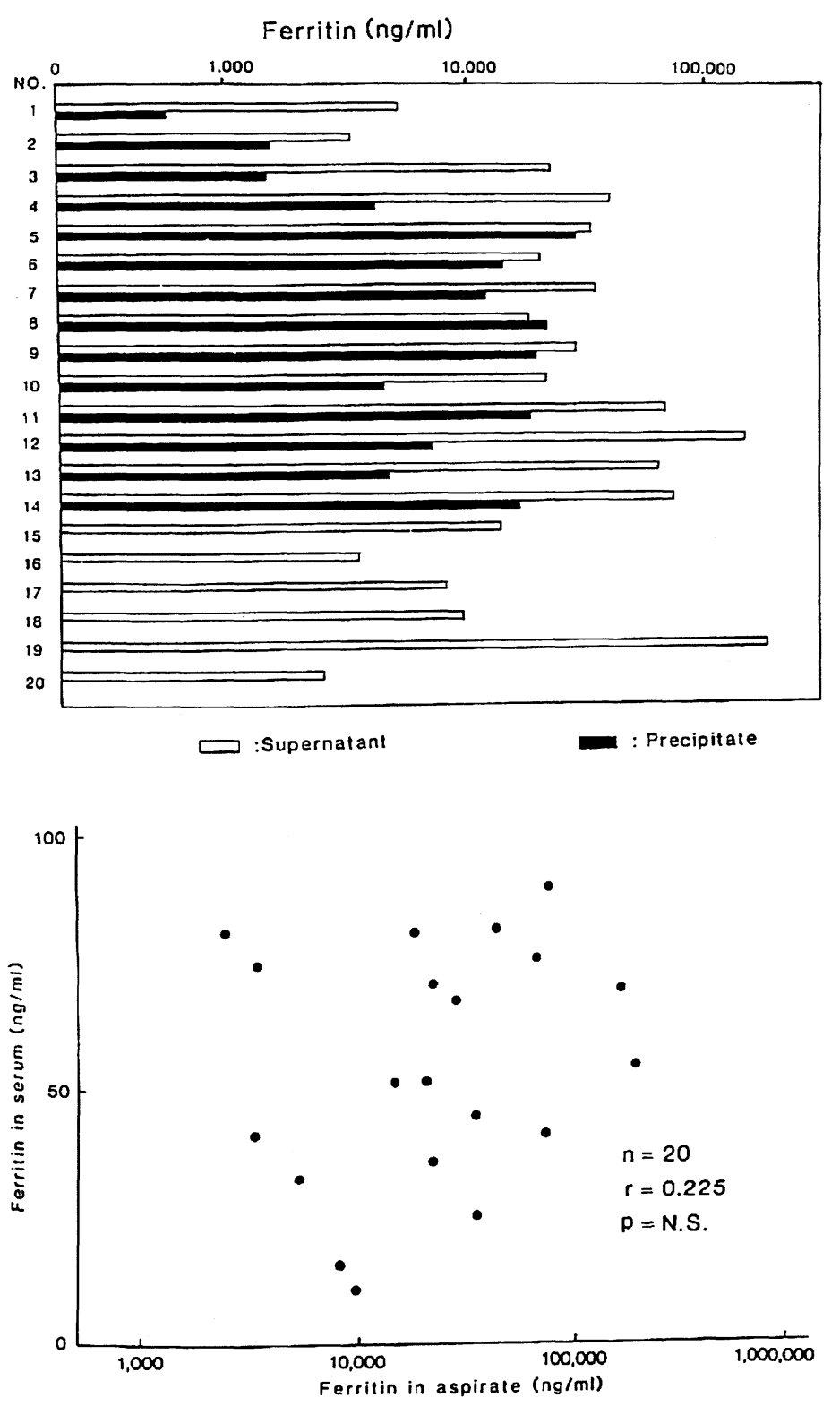

Fig. 1. Ferritin levels in the fluid of thyroid cyst. Each bar shows ferritin levels.
Fig. 2. Correlation between serum ferritin and ferritin in the $3,000 \times \mathrm{g}$ supernatant of aspirate. 
2) CEA, NCA, $\alpha_{1}-A G$ and $C A 19-9$ levels in the aspirate of thyroid cyst

CEA, NCA, $\alpha_{1}-A G$ and CA 19-9 levels in the aspirate were examined. Two cases showed high CEA levels in the supernatant fraction (495 and $88 \mathrm{ng} / \mathrm{ml}$ ).

Seven cases out of 13 patients (7/13) in the supernatant fraction and 6 cases out of 13 patients $(6 / 13)$ in the precipitate fraction had high NCA levels $(>200 \mathrm{ng} / \mathrm{ml}$ ).

Out of 15 cases studied $\alpha_{1}-\mathrm{AG}$ amounts were high in 6 supernatants and in one precipitate. All cases except one showed trace amounts of $\alpha_{1}-\mathrm{AG}$ in the precipitate.

CA 19-9 levels were slightly elevated in 6 cases and extremely elevated in 6 cases in the supernatant (the normal range is $<37$ $\mathrm{U} / \mathrm{ml}$ ). However, only 5 cases showed high levels in the precipitate (Fig. 3).

3) Relationship between ferritin levels and other tumor markers (CEA and CA 19-9) in the supernatant fraction of thyroid cyst fluids

The coefficient of correlation between ferritin and total proteins was 0.39 ( $\mathrm{p}<$ 0.05 ). The coefficients of correlation between ferritin and CEA, and between ferritin and CA 19-9 were $0.04(p>0.05)$ and 0.02 ( $p>0.05)$, respectively.

4) Thyroid function and clinical course in the patients with thyroid cyst

All patients with thyroid cyst showed normal serum T4, T3 and TSH levels. Aspirates of thyroid cyst in all patients were examined histologically, but no malignant findings were observed.

The chronological change in ferritin, CEA, NCA, $a_{1}$-AG and CA 19-9 were examined in some patients with thyroid cyst. The clinical course of one patient is shown in Fig. 4. Ferritin levels in the thyroid cyst fluid of this patient were continuously

Table 1. Ferritin, thyroglobulin and total protein levels in thyroid cyst fluid and thyroid tissues

\begin{tabular}{lccc}
\hline \hline Preparation & Ferritin $(\mathrm{ng} / \mathrm{ml})$ & Thyroglobulin** $(\mu \mathrm{g} / \mathrm{ml})$ & Total protein $(\mathrm{mg} / \mathrm{ml})$ \\
\hline Thyroid cyst fluids & & & \\
Supernatant $(\mathrm{n}=20)$ & 40,116 & 4,856 & 110.9 \\
Precipitate $(\mathrm{n}=14)$ & 11,147 & 445 & 67.7 \\
Thyroid tissues* $(\mathrm{n}=4)$ & 1,013 & $>32,000$ & 107.6 \\
\hline
\end{tabular}

*; The $25,000 \times \mathrm{g}$ supernatant was used for determination

**; Normal serum level was $<27 \mathrm{ng} / \mathrm{ml}$

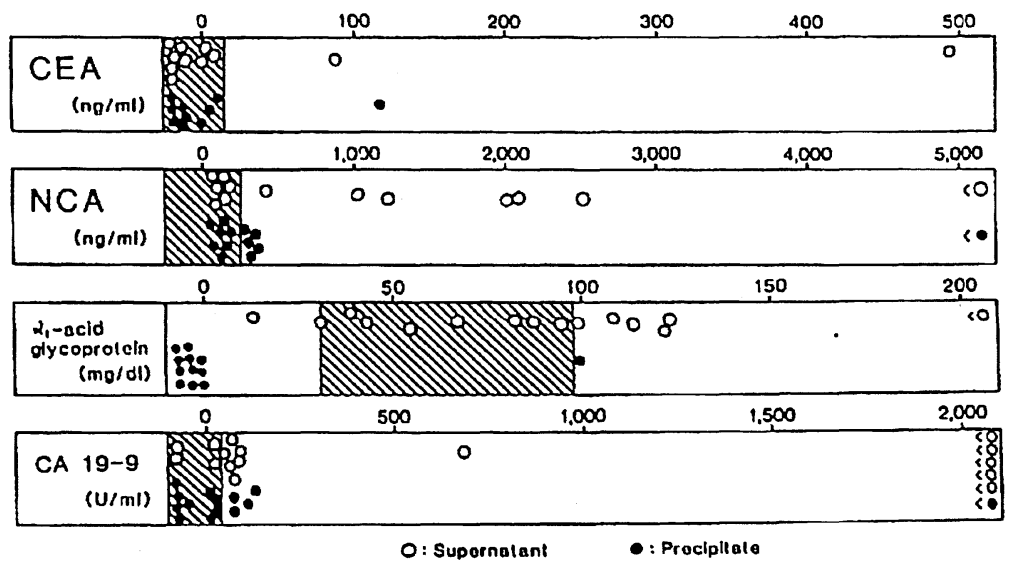

Fig. 3. CEA, NCA, $\alpha_{1}$-acid glycoprotein and CA 19-9 levels in the fluid of thyroid cyst. Shaded area shows the normal range. 
high. Other patients also showed a similar pattern (Data not shown).

5) Thyroglobulin levels in the aspirate and thyroid tissues

Thyroglobulin levels in the aspirate of thyroid cyst were high, especially in the supernatant. The mean level of thyroglobulin was $4,856 \mu \mathrm{g} / \mathrm{ml}$ in the supernatant and $445 \mu \mathrm{g} / \mathrm{ml}$ in the precipitate, respectively. Thyroglobulin levels in the $25,000 \times \mathrm{g}$ supernatant of thyroid tissues were extremely high $(>32,000 \mu \mathrm{g} / 107.6 \mathrm{mg}$ protein) (Table $1)$.

6) Gel-filtration pattern of ferritin in the thyroid cyst fluid using Sepharose $6 B$

The elution pattern of thyroid cyst ferritin on Sepharose 6B is shown in Fig. 5. The peak of ferritin was found in the molecular weight range of approximately 450,000. 125I-labeled ferritin from human liver (Travenol) and human spleen (CIS) showed that the eluted radioactivity has a similar molecular weight (the elution pattern is shown in parenthesis).

7) Con $A$ binding with ferritin in the aspirate of thyroid cyst

Experimental results of Con A binding of ferritin in the thyroid cyst fluid, normal human serum, cancer patient's serum, tumor tissue of hepatoma, and thyroid tissue in Graves' patients are shown in Fig. 6. The unbound percentage in the aspirate was widely distributed (the range was $6.8-90.7$ $\%$ ), although the mean percentage was 38.3 $\%$. The mean unbound percentage in normal human serum and in cancer patient's serum was $20.1 \%$ and $44.3 \%$, respectively.

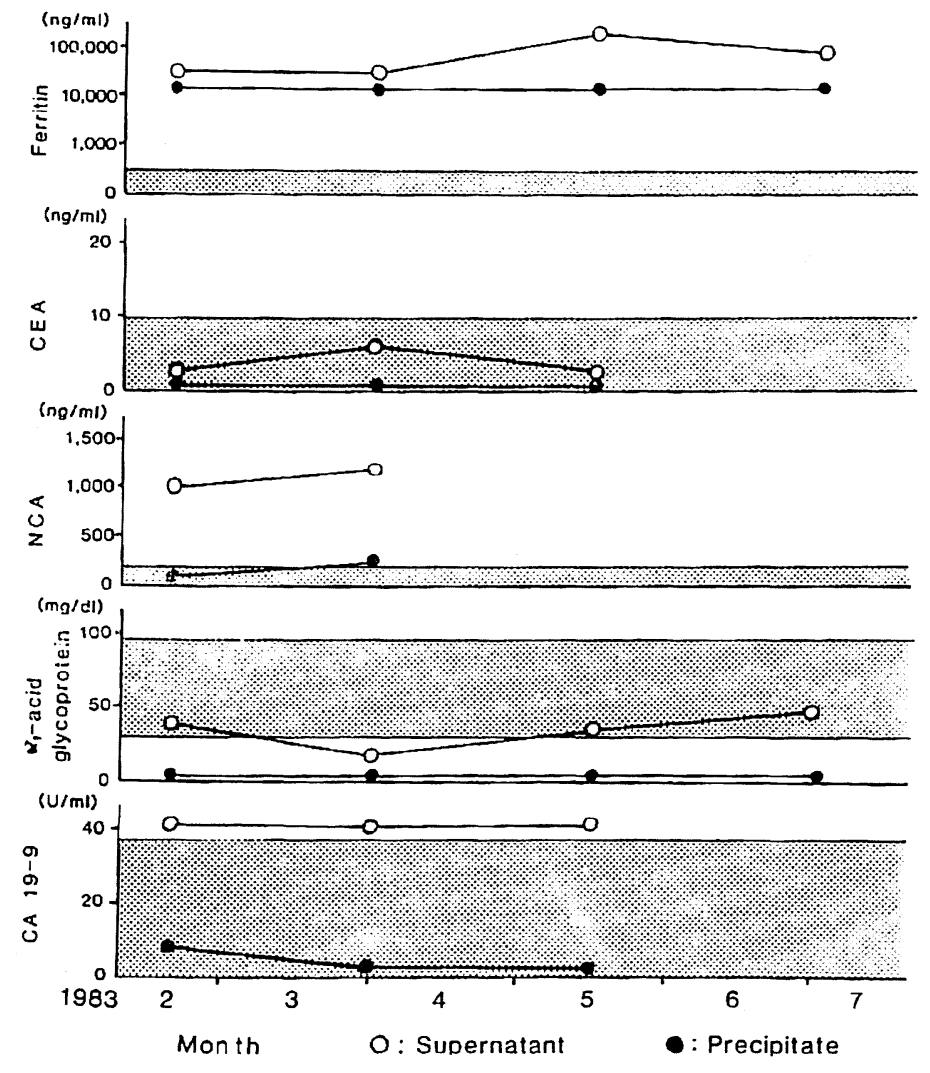

Fig. 4. Time course of ferritin, CEA, NCA, $\alpha_{1}$-acid glycoprotein and CA 19-9 levels in the fluid of thyroid cyst. Shaded area shows the normal range. 
The unbound percentage in tumor tissue of hepatoma and thyroid tissue was $65.4 \%$ and $47.6 \%$, respectively. There was no correlation between ferritin levels and Con A binding of ferritin in the aspirate of thyroid cyst. However, the positive correlation between Con A binding of ferritin in the supernatant and the precipitate from the same sample was statistically significant $(r=$ $0.89, \mathrm{p}<0.01$ ).

\section{Discussion}

Recently, many tumor associated antigens have been available for the monitoring and as diagnostic tools in patients with malignant diseases. Some of them are CEA (Gold and Freedman, 1965), CA 19-9 (Koprowski et al., 1979) and alpha-fetoprotein (Abelev et al., 1963). Ferritin has been known as an iron storage protein and used for diagnosing iron deficiency anemia and iron overload. On the other hand, it was regarded as a tumor associated antigen (Marcus et al., 1979) after

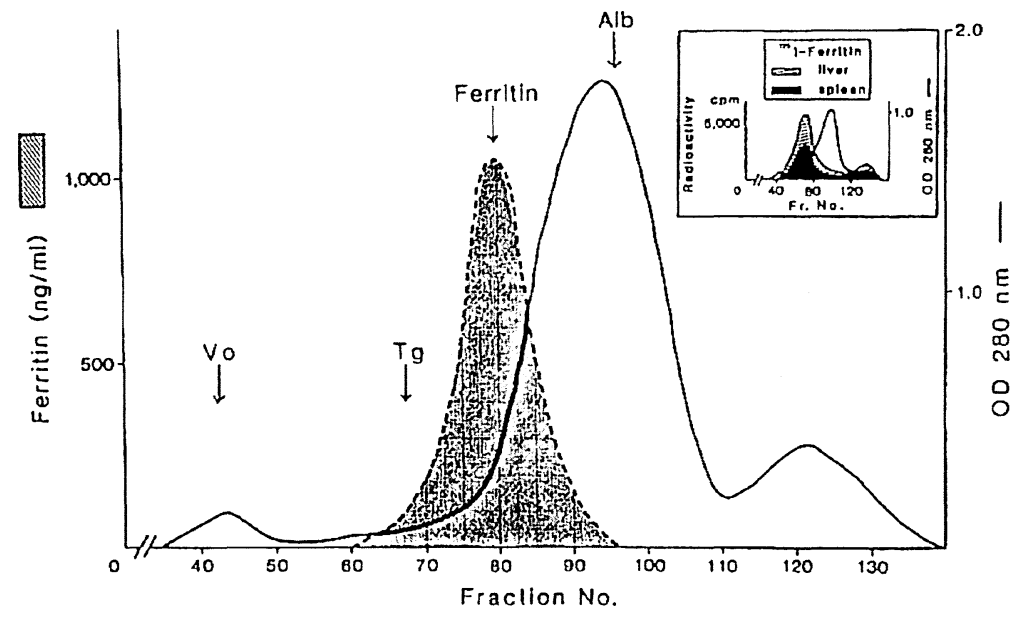

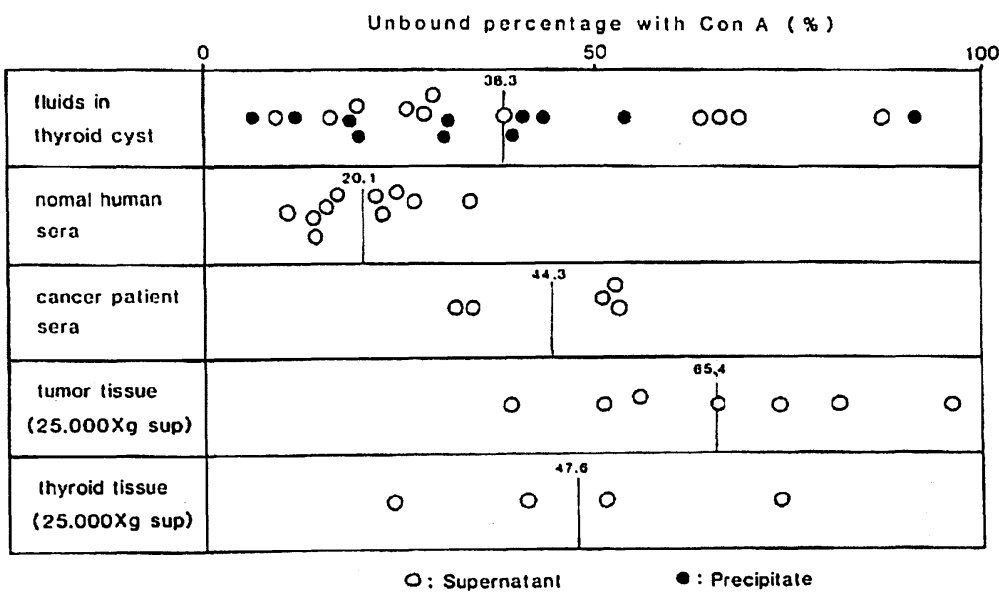

Fig. 5. Gel-filtration of the fluid in thyroid cyst using Sepharose 6B.

Vo; void volume, $\mathrm{Tg}$; thyroglobulin Alb; albumin The parenthesis shows the elution pattern of ${ }^{125}$ I-liver or spleen ferritin containing NHS.
Fig. 6. Con A binding of ferritin in the fluid of thyroid cyst, normal human serum, cancer patient serum, tumor tissue of hepatoma and thyroid tissue. Each bar shows the mean value. 
the development of RIA for ferritin by Addison et al. (1972). A high serum ferritin level in lung cancer (Gropp et al., 1978), leukemia (Jones et al., 1973), primary hepatoma (Kew et al., 1978), and other malignant diseases (Niitsu et al., 1975) has been reported.

In the present experiment we found high ferritin levels in the aspirate of thyroid cyst showing no apparent sign of malignant disease. As far as we know, this is the first report for a high ferritin level in the aspirate of benign thyroid cyst in spite of the fact that the level was normal in serum ferritin. High levels of CEA, CA 19-9 and $\alpha_{1}-\mathrm{AG}$ (one of acute phase reactants) were also observed in some thyroid cyst fluids. However, the frequency and rate of increase of these markers were significantly lower than those of ferritin. We could not compare these tumor markers in cyst fluid from cystic thyroid carcinoma in the present experiment. However, a significantly increased production of ferritin in cyst fluid of thyroids without malignancy was thought highly probable.

Interestingly, high ferritin levels were found not only in the $3,000 \times \mathrm{g}$ supernatant of the fluid, but also the $3,000 \times \mathrm{g}$ precipitate fraction that was released into the $25,000 \times$ $g$ supernatant fraction after freezing. This fact means that ferritin in leucocyte and in macrophage may be released after freezing $\left(-20^{\circ} \mathrm{C}\right)$. The mechanism for increased ferritin levels in cyst fluid of thyroids may be participated in by many factors such as increased production in the inflammatory cells (yellow turbidity and chocolate colored turbidity may be due to an inflammatory mechanism), the increased release from necrotic tissue (this finding was obscure) and the decrease in the decomposition of ferritin in the cyst.

It has been reported that ferritin levels in synovial fluids were high in rheumatoid arthritis and low in osteoarthritis. This means that ferritin may be associated with the reticuloendothelial cells which were stimulated by the inflammatory process (Blake et al., 1980). Another report showed that ferritin production was higher in leukemia cells than in normal leucocytes (Worwood et al., 1974), and that ferritin was detected in T-cells but not B-cells (Nishiya et al., 1980).

An increase in serum ferritin levels in non-malignancy was shown in inflammation (Lipschitz et al., 1974), and this may be the cause of increased ferritin synthesis (Konijn and Hershko, 1977).

The ferritin molecule has a heterogeneity. Linder et al. (1974) suggest that the ferritin molecule is composed of at least two types of subunits ( $\mathrm{H}$ and $\mathrm{L}$ ) and the proportion of these subunits varies with the iron load.

There are many reports on the binding of ferritin with Con $A$, because some ferritins contain carbohydrate moieties (Shinjyo et al., 1975). Worwood et al. (1979) found that only the acidic isoferritins of human serum bound to Con A while the most basic isoferritins did not. Halliday et al. (1979) reported that the plasma half-life of ferritin which was bound to Con $A$ was approximately twice that of ferritin which did not bind. Birgegard (1980) showed that ferritin derived from tissue necrosis is unbound to Con $A$, but serum ferritin is usually bound to Con A. The present data also confirmed that tissue ferritin was unbound to Con $A$ and serum ferritin was bound to Con $A$. This phenomena may be due to the fact that the most plasma proteins become glycosylated during secretion into the plasma. Such a process may be important in determining the properties of circulating ferritin (Worwood et al., 1979).

Ferritin in cyst fluid of thyroid did not show constant binding with Con A. This may indicate that the synthesis and storage of ferritin in the thyroid cyst fluid may be participated by various mechanisms and factors.

Ferritin levels and total proteins in the 
aspirate of thyroid cyst showed weakly positive correlation. The thyroglobulin levels in the aspirate of thyroid cyst was higher than the thyroglobulin level in normal serum, but lower than in thyroid tissue.

CA 19-9 was discovered by Koprowski et al. (1979) with hybridoma techniques, and this antigen is comparatively high in malignancy, especially in patients with pancreas or gastrointestinal tract cancer (Del Villano et al., 1983).

In the present study, CA $19-9$ levels in some cases of the aspirate of thyroid cyst were high although the frequency was low. CEA levels were also high in some cases in spite of the absence of a malignancy. Elevation of CEA, CA 19-9 and $\alpha_{1}$-AG was not as frequent as ferritin. These facts may indicate that increased tumor marker and acute phase reactant in the thyroid cyst fluid may be attributed to the production by the inflammatory cell. It is interesting to note that extremely high ferritin levels in cyst fluid of thyroids without apparent signs of malignancy are common, although plasma ferritin levels are normal. The phenomenon may be attributed not only to the production and release of large amounts of ferritin from inflammatory cells, but also to the decrease in the decomposition of ferritin and to the condensation of ferritin in thyroid cyst fluid.

\section{Acknowledgements}

The author wishes to thank Ayako Kawashima and Tomoko Sato for their help in the preparation of this manuscript.

\section{References}

Abelev, G. 1., S. D. Perova, N. I. Khramakova, Z. A. Postnikova and J. S. Irlin (1963). Production of embryonal $\alpha$-globulin by transplantable mouse hepatomas. Transplantation 1, 174-180.

Addison, G. M., M. R. Beamish, C. N. Hales,
M. Hodgkins, A. Jacobs and P. Llewellin (1972). An immunoradiometric assay for ferritin in the serum of normal subjects and patients with iron deficiency and iron overload. J. Clin. Path. 25, 326-329.

Arosio, P., T. G. Adelman and J. W. Drysdale (1978). On ferritin heterogeneity. J. Biol. Chem. 253, 4451-4458.

Birgegard, G. (1980). The source of serum ferritin during infection. Studies with concanavalin A-sepharose absorption. Clin. Sci. 59, 385-387.

Blake, D. R., P. A. Bacon, E. J. Eastham and K. Brigham (1980). Synovial fluid ferritin in rheumatoid arthritis. $B r$. Med. J. 281, 715716.

Broxmeyer, H. E., J. Bognacki, M. H. Dorner and M. De Sousa (1981). Identification of leukemia-associated inhibitory activity as acidic isoferritins. J. Exp. Med. 153, 1426-1444.

Bryan, C. F. and S. H. Leech (1983). The immunoregulatory nature of iron. Cell Immunol. 75, 71-79.

Del Villano, B. C., S. Brennan, P. Brock, C. Bucher, V. Liu, M. McClure, B. Rake, S. Space, B. Westrick, H. Scoemaker and V. R. Zurawski, Jr. (1983). Radioimmunometric assay for a monoclonal antibody-defined tumor marker, CA 19-9. Clin. Chem. 29, 549-552.

Gold, P. and S. O. Freedman (1965). Demonstration of tumor-specific antigens in human colonic carcinomata by immunological tolerance and absorption techniques. J. Exp. Med. 121, 439-462.

Gropp, C., K. Havemann and F.-G. Lehmann (1978). Carcinoembryonic antigen and ferritin in patients with lung cancer before and during therapy. Cancer 42, 2802-2808.

Halliday, J. W., U. Mack and L. W. Powell (1979). The kinetics of serum and tissue ferritin: Relation to carbohydrate content. $\mathrm{Br}$. J. Haematol. 42, 535-546.

Hamazu, M., Y. Ura, Y. Ochi, S. Hosoda and T. Miyazaki (1984). Studies on NCA-RIA. Abstract of proceedings of the 23rd annual meeting of the Japanese Society of Nuclear Medicine, Jpn. J. Nucl. Med. 21, 578.

Ishida, M., Y. Kajita, Y. Ochi, T. Hachiya, T. Miyazaki, M. Yoshimura and H. Ijichi (1982). Measurement of serum thyroxine binding prealbumin in various thyroidal states by radioimmunoassay. Endocrinol. Jap. 29, 607-613. Jacobs, A., F. R. C. Path and M. Worwood 
(1975). Ferritin in serum: Clinical and Biochemical Implications. New Engl. J. Med. 292, 951-956.

Jacobs, A. and M. Wood (1976). The biochemistry of ferritin and its clinical implications. Progress in Hematology 9, 1-24.

Jones, P. A.E., F. M. Miller, M. Worwood and A. Jacobs (1973). Ferritinaemia in leukaemia and Hodgkin's disease. Br. J. Cancer 27, 27, 212-217.

Kew, M. C., J. D. Torrance, D. Derman, M. Simon, G. M. Macnab, R. W. Charlton and T. H. Bothwell (1978). Serum and tumor ferritins in primary liver cancer. Gut 19, 294299.

Konijn, A. M. and C. Hershko (1977). Ferritin synthesis in inflammation. Br. J. Haematol. 37, 7-15.

Koprowski, H., Z. Steplewski, K. Mitchell, M. Herlyn, D. Herlyn and P. Fuhler (1979). Colorectal carcinoma antigens detected by hybridoma antibodies. Somat. Cell Genet. 5, 957-972.

Linder, M. C., J. R. Moor and H. N. Munro (1974). Subunit heterogeneity in rat liver apoferritin. J. Biol. Chem. 249, 7707-7710.

Lipschitz, D. A., J. D. Cook and C. A. Finch (1974). A clinical evaluation of serum ferritin as an index of iron stores. N. Engl. J. Med. 290, 1213-1216.

Lowry, O. H., N.J. Rosebrough, A. L. Farr and R. J. Randall (1951). Protein measurement with the folin phenol reagent. J. Biol. Chem. 193, 265-275.

Macron, C. I. and Z. G. Macaron (1982). Increased serum ferritin levels in hyperthyroidism. Ann. Intern. Med. 96, 617-618.
Marcus, D. M., N. Zinberg and I. Listowsky (1979). Detection of circulating tumor-associated markers-Ferritin In: Immunodiagnosis of cancer (R.B. Herberman and K. R. McIntire ed.), Ames Yissum, Jerusalem, Israel, pp. 473499.

Niitsu, Y., Y. Kohgo, M. Yokota and I. Urushizaki (1975). Radioimmunoassay of serum ferritin in patients with malignancy. $A n n$. $N$. Y. Acad. Sci. 259, 450-452.

Niitsu, Y. and I. Urushizaki (1978). Measurement of serum ferritin and its clinical application. Acta Haem. Jap. 41, 1301-1308.

Nishiya, K., J. W. Chiao and M. De Sousa (1980). Iron binding proteins in selected human peripheral blood cell sets: Immunofluorescence. $\mathrm{Br}$. J. Haematol. 46, 235-245.

Shinjyo, S., H. Abe and M. Masuda (1975). Carbohydrate composition of horse spleen ferritin. Biochem. Biophys. Acta 411, 165-167.

Walters, G. O., F. M. Miller and M. Worwood (1973). Serum ferritin concentration and iron stores in normal subjects. J. Clin. Pathol. 26, 770-772.

Winkelmann, J. C., C. N. Mariash, H. C. Towle and J. H. Oppenheimer (1981). Thyroidectomy increases rat hepatic ferritin iron. Science 213, 569-571.

Worwood, M., S. J. Cragg, M. Wagstaff and A. Jacobs (1979). Binding of human serum ferritin to concanavalin A. Clin. Sci. 56, 8387.

Worwood, M., M. Summers, F. Miller, A. Jacobs and J. A. Whittaker (1974). Ferritin in blood cells from normal subjects and patients with leukaemia. Br. J. Haematol. 28, 27-35. 